\section{Effect of Milk Renewal on Cell Viability In Vitro at Different Time Frames}

Beatriz Dulcineia Mendes de Souza1, Ana Maria Hecke Alves', Dayane Machado Ribeiro ${ }^{1}$, Luciane Geanini Pena dos Santos ${ }^{1}$, Claudia Maria de Oliveira Simões ${ }^{2}$, Wilson Tadeu Felippe ${ }^{1}$, Mara Cristina Santos Felippe ${ }^{1}$

\author{
'Department of Dentistry, UFSC \\ - Universidade Federal de Santa \\ Catarina, Florianópolis, SC, Brazil \\ ${ }^{2}$ Department of Pharmaceutical \\ Sciences, UFSC - Universidade \\ Federal de Santa Catarina, \\ Florianópolis, SC, Brazil \\ Correspondence: Beatriz Dulcineia \\ Mendes de Souza, Campus \\ Universitário Reitor João David \\ Ferreira Lima s/n, Trindade, \\ 88040-900 Florianópolis, SC, \\ Brasil. Tel: +55-48-3721-4952. \\ e-mail: dentbia@gmail.com
}

The purpose of this study was to evaluate if the renewal of milk as a storage medium every 12,24 and $48 \mathrm{~h}$, is able to increase its ability to maintain human periodontal ligament fibroblasts (PDLF) viability over time. PDLF were soaked in Minimum Essential Medium at $37{ }^{\circ} \mathrm{C}$ (MEM-37) (positive control), tap water (Water) (negative control) and in skimmed milk (44 wells) at $5{ }^{\circ} \mathrm{C}$ and $20^{\circ} \mathrm{C}$. The skimmed milk was renewed every 12 h (Milk-12), $24 \mathrm{~h}$ (Milk-24) and $48 \mathrm{~h}$ (Milk-48) in 11 wells of each plate, and the milk in the remaining 11 wells of each plate was maintained in situ (not renewed milk) (NRM). After $24,48,72,96$ and $120 \mathrm{~h}$, cell viability was determined by the tetrazolium salt-based colorimetric (MTT) assay. Data were statistically analyzed by Kruskal-Wallis, Scheffé and Mann-Whitney tests $(\alpha=5 \%)$. At $5{ }^{\circ} \mathrm{C}$, only Milk-48 was significantly better than NRM. At $20{ }^{\circ} \mathrm{C}$, NRM was more effective than Milk-12 and Milk-24 in all time periods. In relation to the temperature $\left(5^{\circ} \mathrm{C}\right.$ or $\left.20^{\circ} \mathrm{C}\right)$, renewal of milk at $5{ }^{\circ} \mathrm{C}$ was better in maintaining cell viability than the renewal at $20^{\circ} \mathrm{C}$. In conclusion, the renewal of milk was able to increase its ability to maintain cell viability only when performed every $48 \mathrm{~h}$ in milk maintained at $5{ }^{\circ} \mathrm{C}$.
Key Words: milk, periodontal ligament fibroblasts, storage media, tooth avulsion.

\section{Introduction}

When dental avulsion occurs, the replantation of the tooth is strongly recommended as quickly as possible to avoid adverse occurrences, including root resorption $(1,2)$. Storing the avulsed tooth in an adequate medium allows maintaining the viability of the periodontal ligament cells, which provides a more favorable prognosis when the tooth is eventually replanted (3).

Milk is recommended as a transport medium for avulsed teeth (3-11). Besides having low bacterial content $(3,4)$, physiologic osmolality $(230-270 \mathrm{mOsm} / \mathrm{kg})$ and neutral $\mathrm{pH}$ (6.5-6.8), it provides the cells with nutrients (3) and growth factors $(12,13)$. Although there has been some controversy $(6,8)$, it has been suggested that milk with a lower fat content might be more appropriate to maintain PDLF viability than milk with a higher fat content (14). Previous studies indicate that cold milk is more effective than milk at room temperature $(3,10,15$ 17). Low temperatures have the advantage of reducing cellular metabolism (18) and limiting bacterial growth (3), which may affect the prognosis of tooth replantation. Nevertheless, avulsioned teeth are generally stored in a medium at room temperature.

In vitrostudies with cell cultures showed controversial results about the time for which cell viability is maintained $(4,6,7,10,15,17,19-21)$. While some demonstrated effectiveness for only up to $3 \mathrm{~h}(15,19)$ or $6 \mathrm{~h}(4)$, other showed effectiveness for $24 \mathrm{~h}(6,17,20-22)$ or for up to $48 \mathrm{~h}(7,8)$. When culture plates were maintained at 20 ${ }^{\circ} \mathrm{C}$ and $37{ }^{\circ} \mathrm{C}$, milk was the best storage medium for up to 48 and $24 \mathrm{~h}$, respectively (7). As suggested by Blomlof (3), milk probably undergoes a reduction in $\mathrm{pH}$ over time, generating an inappropriate environment for cell survival. In a subsequent study, the same researchers concluded that daily renewal of milk promotes a negative effect on PDLF viability, probably because it causes damage in the organization of the confluent monolayer cells (10).

Considering that milk renewal at greater intervals may compensate its $\mathrm{pH}$ drop and cause less damage in the organization of the confluent monolayer cells and that the storage temperature has an impact on the ability of storage solutions to maintain the viability of PDLF, the purpose of this study was to verify, at $5{ }^{\circ} \mathrm{C}$ and $20{ }^{\circ} \mathrm{C}$, if the renewal of milk every 12,24 or $48 \mathrm{~h}$ is able to increase its ability to maintain the viability of PDLF over time, by the analysis of cell metabolism using MTT assay. It was hypothesized that: (I) renewed milk would exhibit better performance in maintaining cell viability than NRM; (II) Milk-48 would exhibit better performance in maintaining cell viability than Milk-24, which would also exhibit better performance than Milk-12 and (III) renewal of milk at $5{ }^{\circ} \mathrm{C}$ would exhibit better performance over short and long terms in maintaining cell viability than the milk renewal at $20^{\circ} \mathrm{C}$. 


\section{Materials and Methods}

The project was approved by the Ethics Committee for Research with Human Beings (Protocol 074/08).

PDLF were cultured in culture flasks with MEM (Cultilab, Campinas, SP, Brazil) containing 10\% fetal bovine serum (FBS) (Cultilab) and 1\% of penicillin G sodium (10.000 UI), streptomycin $(10 \mathrm{mg})$ and amphotericin B $(25 \mu \mathrm{g})$ (collectively, PSA) (Cultilab) in a humidified incubator with $5 \% \mathrm{CO}_{2}$ and $95 \%$ air at $37{ }^{\circ} \mathrm{C}$ (HF 212; Fanem, São Paulo, $\mathrm{SP}, \mathrm{Brazil})$. Cells from the passages 5 to 10 were used.

For the experiment, the cells $\left(8 \times 10^{3}\right.$ cells per well) were seeded in ten 96-well culture plates (TPP, Trasadingen, Switzerland) and incubated at $37{ }^{\circ} \mathrm{C}$ with $5 \% \mathrm{CO}_{2}$. At confluence, MEM was removed from 55 wells in each plate. Forty-four of them were then filled with $100 \mu \mathrm{L}$ of skimmed pasteurized long life milk (Parmalat, São Paulo, SP, Brazil) ( $\mathrm{pH}$ 6.8), from a package maintained at room temperature. The remaining 11 wells were filled with $100 \mu \mathrm{L}$ of tap water (Water) (pH 7.6) as a negative control. Five among the 10 plates were maintained at $5{ }^{\circ} \mathrm{C}$ and the other 5 plates at 20 ${ }^{\circ} \mathrm{C}$. The milk was renewed every $12 \mathrm{~h}$ (Milk-12), $24 \mathrm{~h}$ (Milk24) and $48 \mathrm{~h}$ (Milk-48), or left in situ (not renewed milk) (NRM) $(n=11)$. For renewal, the milk was carefully aspirated and immediately replaced with $100 \mathrm{~mL}$ of milk from newly opened packages. Other 5 plates with confluent PDLF were soaked in MEM at $37^{\circ} \mathrm{C}$ as positive control (MEM-37) for cell growth. After 24, 48, 72, 96 and $120 \mathrm{~h}$ the storage media in 2 plates (one at $5{ }^{\circ} \mathrm{C}$ and the other at $20{ }^{\circ} \mathrm{C}$ ) were replaced by MTT solution [3-(4,5-dimethylthiazol2-yl)-2,5-diphenyl tetrazolium bromide] (Sigma Chemical Co., St. Louis, MO, USA) and the plates were incubated at $37^{\circ} \mathrm{C}$. After $4 \mathrm{~h}$, the MTT solution was removed and 100 $\mu \mathrm{L}$ of dimethylsulfoxide (DMSO) was added to the wells. Cell viability was determined by measuring the optical density at $540 \mathrm{~nm}$ in a spectrophotometer (ELx 800; BioTek Instruments-Inc, Winooski, VT, USA).

\section{Statistical Analysis}

Statistical analysis of the data was made using the Kruskal-Wallis test, complemented by the Scheffé test and Mann-Whitney tests. Statistical differences were considered significant at $p<0.05$. Tests were performed using SPSS 20.0 (SPSS Inc., Chicago, IL) software. The level of significance was set at $5 \%$.

\section{Results}

The initial absorbance value was 0.33 . The mean absorbance values, which represent PDLF viability for each tested medium and storage periods, are shown in Figure $1\left(5{ }^{\circ} \mathrm{C}\right)$ and Figure $2\left(20^{\circ} \mathrm{C}\right)$. The Kruskal-Wallis test showed time-dependent results according to the analyzed experimental solution for both temperatures $(p<0.001)$. At both temperatures the results revealed that MEM was significantly more effective in maintaining cell

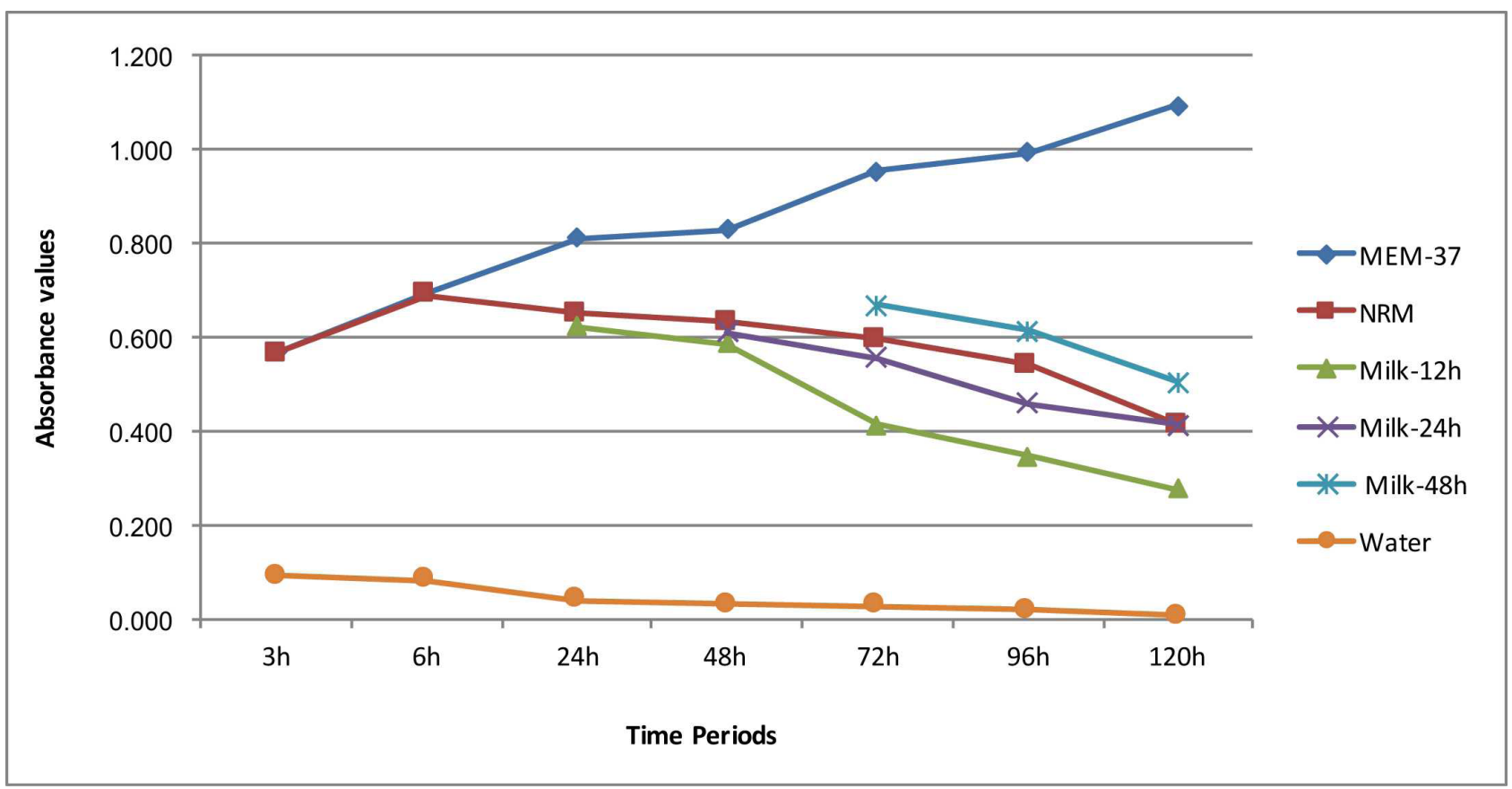

Figure 1. Mean absorbance values, which represent PDL cell viability for each tested medium at $5{ }^{\circ} \mathrm{C}$ in different periods of time. MEM-37: minimum essential medium at $37^{\circ} \mathrm{C}$; NRM: not renewed milk; Milk-12: milk renewed every $12 \mathrm{~h}$; Milk-24: milk renewed every 24 h; Milk-48: Milk renewed every $48 \mathrm{~h}$; Water: tap water. 
viability than the other groups $(p<0.001)$. All groups were significantly better than Water, at all analyzed time periods. At $5{ }^{\circ} \mathrm{C}$, renewal of the milk produced a positive effect on cell viability only when performed each $48 \mathrm{~h}(\mathrm{p}<0.001)$. When performed every 12 or $24 h$, the number of viable cells decreased. At $20{ }^{\circ} \mathrm{C}$, NRM was more effective in maintaining cell viability than Milk-12 or Milk-24 $(p<0.05)$. Milk-48 and NRM showed similar performance at 96 and $120 \mathrm{~h}$ ( $\mathrm{p}>0.05)$.

As regards the temperature, Mann-Whitney test showed that renewal of milk was less damaging in the experiments carried out at $5{ }^{\circ} \mathrm{C}(\mathrm{p}<0.05)$.

\section{Discussion}

In more serious accidents, where other injuries are a priority, avulsed teeth may not be able to be replanted for a few days. Therefore, it should be stored in a physiological environment in order to maintain the viability of the periodontal ligament cells on the root surface.

Milk is a proven storage medium for avulsed teeth $(6,8,11)$, but cell culture studies have shown that its effectiveness decreases over time (6-8), probably because the drop in its $\mathrm{pH}$ creates an unsuitable environment for cell survival (3). Thus, it was hypothesized that the renewal of milk for storing the avulsed tooth could prevent the drop in its $\mathrm{pH}$. However, an in vitro study showed that milk renewal every $24 \mathrm{~h}$ produced a negative effect on cell viability (10).
Therefore, milk renewal at greater intervals may compensate its $\mathrm{pH}$ drop and cause less damage in the organization of the confluent monolayer cells. In this study, the milk was renewed every 12,24 or $48 \mathrm{~h}$ to elucidate this issue.

The first hypothesis was partially accepted, because only Milk- 48 at $5^{\circ} \mathrm{C}$ exhibited better performance in maintaining cell viability than NRM. At both temperatures, Milk-12 or Milk-24 decreased its ability to maintain cell viability. At $20{ }^{\circ} \mathrm{C}$, Milk-48 also did not increase its effectiveness. The results in the present study agree with the previous study that showed that NRM exhibited better performance in maintaining cell viability than Milk-24 (10).

The second hypothesis was accepted, because Milk-12 was more deleterious to cells than Milk-24 which was also more deleterious than Milk-48, at both temperatures. Probably in Milk-48 there was less damage in the organization of the confluent monolayer cells. This fact confirms that the aspiration and replacement of milk affect adversely the confluent monolayer cells, by releasing the cells from wells, as described by a previous study (10). According to the authors, the removal of growth factors and chemical cell mediators (proteins) caused by replacing the milk, may also have disturbed cellular metabolism and the reversion of tetrazolium salts in formazan crystals. In a clinical tooth avulsion situation, possibly the renewal of milk is less harmful since it does not require aspiration of the product.

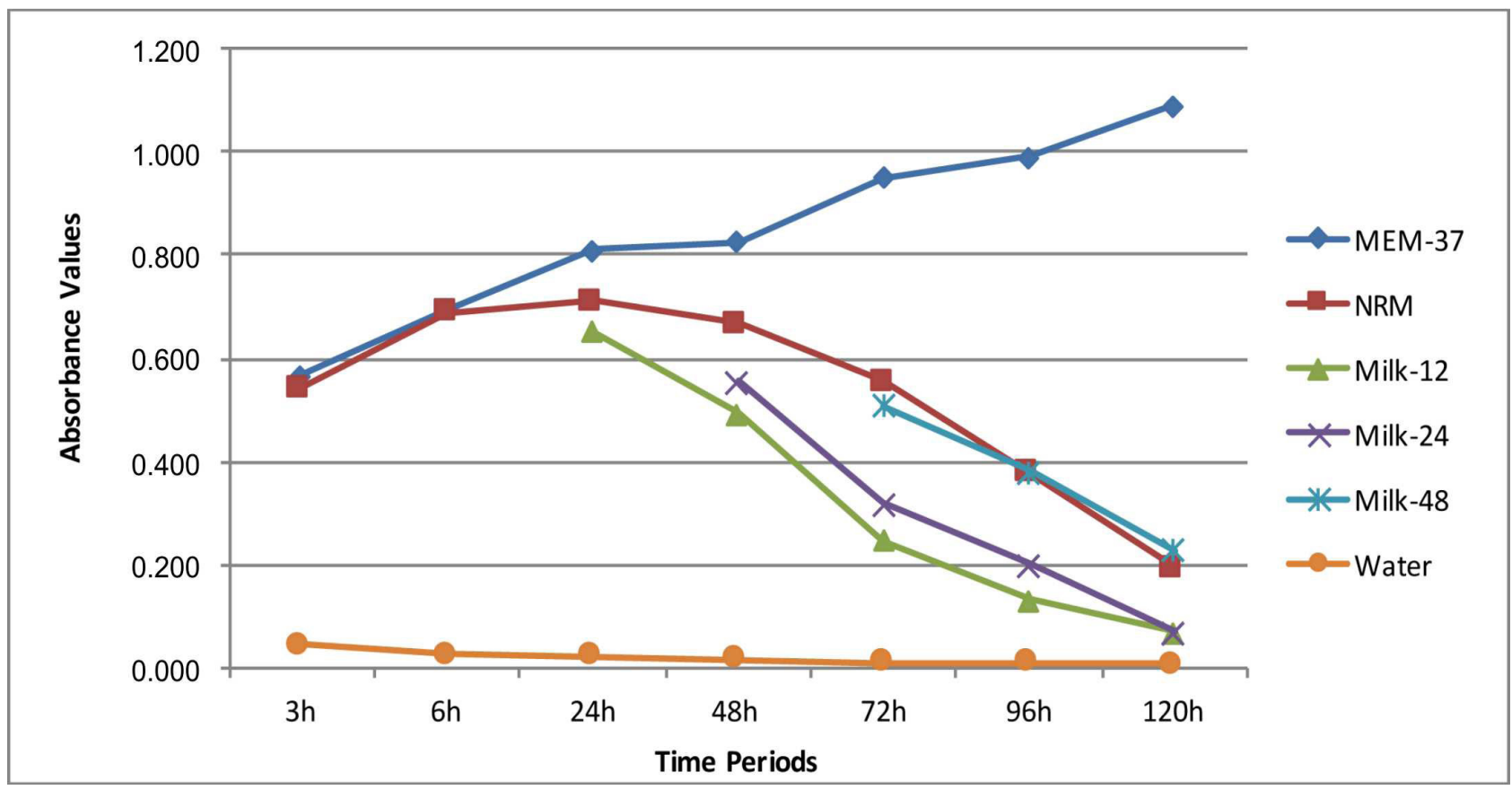

Figure 2. Mean absorbance values, which represent PDL cell viability for each tested mediu at $20{ }^{\circ} \mathrm{C}$ in different periods of time. MEM-37: minimum essential medium at $37^{\circ} \mathrm{C}$; NRM: not renewed milk; Milk-12: milk renewed every $12 \mathrm{~h}$; Milk-24: milk renewed every 24 h; Milk-48: Milk renewed every $48 \mathrm{~h}$; Water: tap water. 
This study was carried out at $5{ }^{\circ} \mathrm{C}$ and $20{ }^{\circ} \mathrm{C}$ to allow comparisons. The third hypothesis was accepted because renewal of milk at $5^{\circ} \mathrm{C}$ exhibited better performance in short and long terms in maintaining cell viability than the milk renewed at $20^{\circ} \mathrm{C}$. From $48 \mathrm{~h}$ onwards, milk replacement at $5{ }^{\circ} \mathrm{C}$ was less detrimental to the cells. Probably, the lower temperatures provided greater stability to the confluent cells, preventing their detachment, which seems to have occurred when the replacement was done by milk at 20 ${ }^{\circ} \mathrm{C}$. In this study, the results showed that the NRM was effective in maintaining human fibroblast viability and was not influenced by temperature for up to $48 \mathrm{~h}$, agreeing with other studies $(7,10)$. From $72 \mathrm{~h}$ onwards, NRM at 5 ${ }^{\circ} \mathrm{C}$ showed better results than NRM at $20{ }^{\circ} \mathrm{C}$. However, it is important to highlight that from $72 \mathrm{~h}$ onwards the performance of NRM at $5{ }^{\circ} \mathrm{C}$ was statistically poorer than the one of MEM- 37 .

It is worth noting that the design of the present study has some limitations. The populations of "seemingly identical" cells are heterogeneous with phenotypic differences (23). Additionally, the method used for counting the number of cells was the MTT assay. Compared with the traditional methods, this assay is more efficient, more reliable and faster. However, the employed methodology has limitations $(7,24)$. It measures metabolic activity (mitochondrial function of PDLF), not necessarily the viability and cell proliferation (25). Some cells can be viable but not necessarily with a great metabolic activity (26). Therefore, further studies are required to evaluate other parameters of cell viability using other cell culture models, like apoptotic cell death using WST-1 cell viability assays (14), trypan blue exclusion test $(6,7)$, nucleocounter $(20)$ and microarray analysis (5). Studies in vivo (9) should also be performed.

Despite the limitations of the current study, it was concluded that only Milk- 48 was able to increase the ability to maintain PDLFviability in the experiments carried out at $5{ }^{\circ} \mathrm{C}$. It must be emphasized that this research was based on in vitro cell cultures and the conditions of PDLF may not be similar with the conditions of the cells adhered to the root surface of a real avulsed tooth. On the other hand, considering the amount of collagen surrounding the cells, it is possible that in a clinical situation, milk renewal would not affect the cells as much as in this in vitro situation.

\section{Resumo}

0 objetivo deste estudo foi avaliar se a renovação do leite, a cada 12, 24 e $48 \mathrm{~h}$, é capaz de aumentar sua capacidade de manter a viabilidade de fibroblastos do ligamento periodontal humano (FLPH) ao longo do tempo. FLPH foram conservados em Meio Essencial Mínimo a $37{ }^{\circ} \mathrm{C}(\mathrm{MEM}-37)$ (controle positivo), água da torneira (água) (controle negativo) e em leite desnatado ( 44 poços) a $5^{\circ} \mathrm{C}$ e $20^{\circ} \mathrm{C}$. 0 leite desnatado foi renovado a cada $12 \mathrm{~h}$ (leite-12), $24 \mathrm{~h}$ (leite-24) e $48 \mathrm{~h}$ (leite-48) em 11 poços de cada placa, e em outros 11 poços de cada placa o leite foi deixado in situ (leite não renovado) (LNR). Depois de 24, 48, 72, 96 e 120 h, a viabilidade celular foi determinada pelo ensaio colorimétrico à base de sal tetrazólio (MTT). Os dados foram analisados estatisticamente pelos testes de Kruskal-Wallis, Scheffé e Mann-Whitney $(\nabla=5 \%)$. A $5{ }^{\circ} \mathrm{C}$, somente 0 leite-48 foi significantemente melhor do que o LNR. A $20{ }^{\circ} \mathrm{C}$, LNR foi mais efetivo do que o leite-12 e leite-24 em todos os periodos de tempo. Em relação à temperatura $\left(5^{\circ} \mathrm{C}\right.$ ou $\left.20^{\circ} \mathrm{C}\right)$, a renovação do leite a $5{ }^{\circ} \mathrm{C}$ foi melhor na manutenção da viabilidade celular do que a renovação a $20^{\circ} \mathrm{C}$. Concluindo, a renovação do leite foi capaz de aumentar sua habilidade em manter a viabilidade celular apenas quando realizada a cada $48 \mathrm{~h}$ no leite mantido a $5{ }^{\circ} \mathrm{C}$.

\section{References}

1. Blomlof L, Lindskog S, Andersson L, Hedstrom K-G, Hammarstrom L. Storage of experimentally avulsed teeth in milk prior to replantation. J Dent Res 1983;62:912-916.

2. Trope M. Avulsion of permanent teeth: Theory to practice. Dent Traumatol 2011;27:281-294.

3. Blomlof L. Milk and saliva as possible storage media for traumatically exarticulated teeth prior to replantation. Swed Dent J Suppl 1981;8:126.

4. Lindskog $\mathrm{S}$, Blomlof $\mathrm{L}$, Hammarstrom L. Mitoses and microorganisms in the periodontal membrane after storage in milk or saliva. Scand J Dent Res 1983;91:465-472.

5. Choi SC, Seo YH, Bae WJ, Lee HS, Choi YC, Kim EC. Milk activates the expression of cytokines via nrf2/ho-1 pathway in human periodontal ligament cells. Dent Traumatol 2015;31:457-464.

6. Moura CC, Soares PB, de Paula Reis MV, Fernandes Neto AJ, Zanetta Barbosa D, Soares CJ. Potential of coconut water and soy milk for use as storage media to preserve the viability of periodontal ligament cells: An in vitro study. Dent Traumatol 2014;30:22-26.

7. Souza BD, Luckemeyer DD, Felippe WT, Simoes CM, Felippe MC. Effect of temperature and storage media on human periodontal ligament fibroblast viability. Dent Traumatol 2010;26:271-275.

8. Souza BD, Luckemeyer DD, Reyes-Carmona JF, Felippe WT, Simoes CM, Felippe MC. Viability of human periodontal ligament fibroblasts in milk, Hank's balanced salt solution and coconut water as storage media. Int Endod J 2011;44:111-115.

9. Paula Reis MV, Moura CC, Soares PB, Leoni GB, Sousa-Neto MD, Barbosa DZ, et al.. Histologic and micro-computed tomographic analyses of replanted teeth stored in different kind of media. J Endod 2014;40:665-669.

10. Souza BD, Luckemeyer DD, Felippe WT, Alves AM, Simoes CM, Felippe MC. Effect of milk renewal on human periodontal ligament fibroblast viability in vitro. Dent Traumatol 2012;28:214-216.

11. Poi WR, Sonoda CK, Martins CM, Melo ME, Pellizzer EP, de Mendonca $M R$, et al.. Storage media for avulsed teeth: A literature review. Braz Dent J 2013;24:437-445.

12. Belford DA, Rogers ML, Regester GO, Francis GL, Smithers GW, Liepe IJ, et al.. Milk-derived growth factors as serum supplements for the growth of fibroblast and epithelial cells. In vitro Cell Dev Biol Animal 1995;31:752-760.

13. Gauthier SF PY, Maubois J-L. Growth factors from bovine milk and colostrum: Composition, extraction and biological activities. Lait 2006;86:90-125.

14. Harkacz OM Sr, Carnes DL Jr, Walker WA III. Determination of periodontal ligament cell viability in the oral rehydration fluid Gatorade and milks of varying fat content. J Endod 1997;23:687-690.

15. Blomlof L, Otteskog P. Viability of human periodontal ligament cells after storage in milk or saliva. Scand J Dent Res 1980;88:436-440.

16. Sigalas E, Regan JD, Kramer PR, Witherspoon DE, Opperman LA. Survival of human periodontal ligament cells in media proposed for transport of avulsed teeth. Dent Traumatol 2004;20:21-28.

17. Ashkenazi M, Sarnat $H$, Keila S. In vitro viability, mitogenicity and clonogenic capacity of periodontal ligament cells after storage in six different media. End Dent Traumatol 1999;15:49-156.

18. Barile F. Introduction to in vitro cytotoxicology: Mechanisms and 
methods. Boca Raton, FL: CRC Press 1994:12-14.

19. Huang SC, Remeikis NA, Daniel JC. Effects of long-term exposure of human periodontal ligament cells to milk and other solutions. J Endod 1996;22:30-33.

20. Hwang JY, Choi SC, Park JH, Kang SW. The use of green tea extract as a storage medium for the avulsed tooth. J Endod 2011;37:962-967.

21. Silva EJ, Rollemberg $C B$, de Souza Coutinho-Filho T, Zaia AA. A multiparametric assay to compare the cytotoxicity of soy milk with different storage media. Dent Traumatol 2013;29:319-322.

22. Casaroto AR, Hidalgo MM, Sell AM, Franco SL, Cuman RK, Moreschi E, et al.. Study of the effectiveness of propolis extract as a storage medium for avulsed teeth. Dent Traumatol 2010;26:323-331.

23. Altschuler SJ, Wu LF. Cellular heterogeneity: Do differences make a difference? Cell 2010;141:559-563.
24. Chan GK, Kleinheinz TL, Peterson D, Moffat JG. A simple high-content cell cycle assay reveals frequent discrepancies between cell number and ATP and MTS proliferation assays. Plos One 2013;8: e63583 (doi:10.1371/journal.pone.0063583).

25. Riss TL, Moravec RA, Niles AL, Duellman S, Benink HA, Worzella TJ, et al.. Cell viability assays. Assay Guidance Manual 2013 (Updated 2016);1-31.

26. Wang P, Henning SM, Heber D. Limitations of MT and MTS-based assays for measurement of antiproliferative activity of green tea polyphenols. Plos One 2010;5: e10202.

Received February 3, 2017 Accepted April 7, 2017 